\title{
CHALCEDONIAN PERSONALISM ACCORDING TO COLIN PATTERSON
}

\begin{abstract}
A b s t r a c t. Colin Patterson from Melbourne, Australia presents Personalism of the Council of Chalcedon (451). He considers the Mystery of the Holy Trinity, the Person of Jesus Christ and the image of God in each human person. He emphasizes especially the Person-Nature relation in Trinitology, Christology and Anthropology.
\end{abstract}

Key words: the Council of Chalcedon; personalism; relation; person; nature.

\section{THE MYSTERY OF THE HOLY TRINITY}

At Nicaea I (325) is the distinction between nature and person so articulated that in no case is there any attempt to philosophically connect the two concepts, as, for example, we find in the Cappadocians' notion that a person is the individual instance of the genus of human nature. In the Trinity are three Persons but only One Nature: person and nature are not interchangeable. And yet the Son is God, just as the Father is God and the Holy Spirit is God. And on the basis that each of the Persons is a particularization (better to say a uniqueness) of a single Divine Nature. According to von Balthasar, the notion of "person" is defined negatively or apophatically in terms of what it is not: "Persona est philosophice ineffabilis, immo incogitabilis - The Person is philosophically in-

Fr. Loenard SANYU is a Doctoral student specializing in Dogmatic Theology at Cardinal Stefan Wyszyński University, Warsaw. He is a priest of the Catholic Diocese of Hoima-Uganda. He received Bachelor's degrees in Philosophy and Theology of the Pontifical Urbaniana University, Rome and a Master's degree in Religious and Theological Studies from Makerere University, Kampala; e-mail: sanyuleonard@gmail.com; ORCID: http://orcid.org/0000-0002-1599-0102. 
effable, indeed unthinkable." Von Balthasar and Ratzinger have emphasized, the doctrine of the patristic era attributed only relationships of origin to the particularity of each of the Divine Persons. The Son's only distinctive characteristic is that he was eternally begotten of the Father. To preserve the actual Divinity of each of the Persons, the common features of Divinity had to be ascribed to them but beyond that, nothing of non-relational qualities are attributable. For Augustine, Trinitarian relations are subsistent or subsisting relations. Also for Aquinas, the Divine Persons are the subsisting relations themselves. ${ }^{2}$ Personsin-relation is truly an independent "ontological" category, irreducible to that of substance. Whereas accidental relations, such as "being next to" or "being employed by" presuppose two objects moving into spatial proximity to each other, for persons-in-relation the reverse happens: two objects only come into existence when a relation is constituted. The Father is only the Father and the Son is only the Son insofar as there exists the relationship Unbegotten-Begotten. Richard of St. Victor's definition spiritualis naturae incommunicabilis existentia (the incommunicably proper existence of a spiritual nature) shows the concept of "person" as operating at the level of existence rather than of essence. He replaces the substantia of Boethius with the term existentia. Von Balthasar understands him to mean that the Father, and the Son and the Holy Spirit cannot be placed within the category of "substance" but belong to a logically prior, non-substantial reality, "ex-sistentia," as a spiritual subject that earns the name person only by going out beyond itself (ex )- in God as something relative.

It is Ratzinger who spells out more fully the notion of persons-in relation. In God, person is the pure relativity of being turned toward the other; it does not lie on the level of substance-the substance is One-but on the level of dialogical reality, of relativity towards the other. For Augustine, in God there is nothing accidental, but only substance and relation. ${ }^{3}$ Relation is recognized as a third specific fundamental category between substance and accident, the two great categorical forms of thought in Antiquity. For Aristotelian categories relation belongs to the accidents of a substance, and cannot be in any sense by thought of as a third separate ontological fundamental. The reality of a special kind of relation, a substantial relation, was hinted upon by Aquinas as a way of characterizing the relations between the divine Persons of the Trinity. But according to Ratzinger, this did not capture

1 Colin Patterson, Chalcedonian Personalism: Rethinking the Human (Oxford: Peter Lang Ltd, 2016), 108.

2 Cf. ibidem, 109.

${ }^{3}$ Cf. ibidem, 110. 
the genuine sense of "relation" that he believes had been intuited by some, like Augustine, even in the patristic period. ${ }^{4}$

According to Dr. Patterson "persons-in-relation" is a cumbersome label for an ontological primitive because it is not simple, unlike substance and accident. Therefore it is better to see the terminology of "persons-in-relation" as primarily conceptual fence-work. We do not use the term "person" to denote a basic category since this can, and is, easily translated into "spiritual substance" or merely a subset of the broader category of "substance." Nor can we speak of "relation" tout court, for such a term covers accidental relations as well. Persons-in-relation proposes the necessity of moving beyond that simple "looking" model but points to much more reality. It opens the door to exploring that further reality. It leads not so much to activities such as interest or analysis, but Worship. I find this in line with the fact that "person" as applied to the Holy Trinity is not subject of comprehension but rather he who searches in the inner-life of the Holy Trinity cannot but end up in Worship. For he will not but Worship. Patterson's' development and discussion on the reality of Person as we speak of the Trinity leads us to Faith and Worship. For if there is no room for this faith and worship due to the Divine Persons, "Person" will only remain a philosophical concept void of content. It would be like a blind reason or philosophy that seeks what it cannot find that is seeking for reality out of reality or seeking for reality away from reality. The concept of Person as applied to the Trinity void of faith, would only remain at the level of idealism.

The notion of "person" as used in Trinitarian theology referring to the Divine Persons, belong to its own category, namely, "Persons-in-relation" rather than "substance." The main search of this article is on the relation between nature and person. Patterson is giving us an interesting relation namely that of faith and worship. The Tri-Person God is worshipped, God the Father, God the Son, God the Holy Spirit. This is emanating directly from the ontological understanding of the "Person-Nature" inseparable link as applied to the Holy Trinity. The God to be worshiped is the God we come to, through Special Revelation or Supernatural Revelation. The Tri-Person God. Ratzinger sees a very wonderful connection between faith and reason. That true reason is that which ends in Faith. Reason that has no space for faith is not reasonable reason. Faith does not destroy philosophy but defends it. ${ }^{6}$ God is Being in Three Persons. The Three

${ }^{4}$ Cf. ibidem, 111.

5 Cf. ibidem, 111.

${ }^{6}$ Cf. Joseph Ratzinger, Faith, Philosophy and Theology (Minnesota: College of St. Thomas Press, 1985). 
Persons that exist in God are in their Nature Relations. They are, therefore, not substances that stand next to each other, but they are real existing relations, and nothing besides. In God, person means relation. Relation, being related, is not something superadded to the person, but is the person Himself. In His nature, the person exists only as relation. Put more concretely, the First Person does not generate in the sense that the act of Generating the Son is added to the already complete person, but the Person is the deed of Generating, of giving Himself, of streaming Himself forth. The person is identical with this act of self-donation. ${ }^{7}$ When speaking of the Divine Persons, we are not to introduce any thought of entities or natures being related to each other such that we end up with three distinct beings. In the Trinity, every care must be taken to avoid the temptation to incorporate into discussion of persons any "substance" talk whatsoever. Personhood in Trinitarian discourse is truly a theological concept though not only theological. The Divine Persons are always Persons-in-relation. Patterson asserts that for the sake of meaningful worship, the Divine Persons are to be considered as "poles" of the relations of origin rather than as purely the relations themselves. ${ }^{8}$

\section{THE PERSON OF JESUS CHRIST}

Whereas Persons cannot be described in terms of nature or substance, at the same time there exists an unalienable relationship between Persons and Nature which when not considered we cannot talk of real persons. That is why Chalcedon (451) defined that: "One and the same (Person) Christ only begotten Son [...] acknowledged in two natures, without mingling, without change, indivisibly, undividedly, the distinction of the natures nowhere removed on account of the union but rather the peculiarity of each nature being kept, and uniting in one person and substance not divided or separated into two persons, but one and the same Son only begotten God Word, Lord Jesus Christ." With this in mind, we can now proceed to look at the Person of Jesus under the themes: Divine-Human relationship and Human Nature is like that of Christ.

\section{Divine-Human Relationship}

In Christ, there are two natures in One Person. There is in Christ, Divine Nature and Human Nature, but He is One Divine Person. The relationship between

\footnotetext{
7 Cf. Patterson, Chalcedonian Personalism, 40.

8 Cf. ibidem, 128.

9 Henry Denzinger, The Sources of Catholic Dogma (Freiburg: Herder \& Co., 1954), n. 148.
} 
Person and Nature cannot be positively expressed since they are two distinctive "realities" associated both with God and also with each human being. Because persons cannot be positively described-neither can we provide positive accounts of the relation that exists between Person and Nature, even though we know that they go together such that there is no person without a nature, or in terms of the categories of nature, they constitute one reality. ${ }^{10}$ We cannot talk of person without nature, even if we do not describe person in terms of nature. According to Patterson, Chalcedonian Personalism places persons at its Centre, but is unique in that it draws for its inspiration upon the doctrinal development of that concept as epitomized but not limited by the teachings of the Council of Chalcedon. ${ }^{11}$ By using the term "Chalcedon" as a pars pro toto, that is, as representative of the process as a whole, Patterson leads us to a wide understanding of the issues surrounding the development of the notion of person and its use at wider scope than the Council of Chalcedon alone.

There is a very close relationship between person and nature. Yet this relation is not absolute identity since we cannot say for example "God is Christ"12 The Cappadocian Fathers attempted to specify the relation between person and nature in terms of the particular and general. Others followed them, for example, Maximus the Confessor wrote-Common and Universal, that is, generic, is, according to the Fathers the essence and nature, for they say that these two are identical with each other. Individual and particular is the hypostasis and person, for these two are identical with each other. ${ }^{13}$ For Boethius (c.480-c.525), since Person cannot exist apart from nature and since natures are either substances or accidents, it remains that Person is properly applied to substances. Here we find a closer specification of the link between person and nature. Boethius came to his famous definition of a "person" as an "individual substance of rational nature." Nature is the specific or defining property of any substance. Person fits in here as that which has a nature (rationality) underlying it or serving as its substrate. Individual substance is to be understood as the equivalent of subsistence, or a substance only in so far as it has been determined or individuated. Boethius uses the Aristotelian understanding of the relation between substance and subsistence, and of reason as the defining, distinctive quality of man, so as to more specifically express the general person-nature relation applicable to both human persons and Divine Persons.

\footnotetext{
${ }^{10}$ Cf. Patterson, Chalcedonian Personalism, 225.

${ }^{11} \mathrm{Cf}$. ibidem, xiv.

${ }^{12} \mathrm{Cf}$. ibidem, 19.

${ }^{13} \mathrm{Cf}$. Maximus the Confessor as quoted by Patterson, Chalcedonian Personalism, 20.
} 
According to John of Damascus (c.676-749) there is that which is more particular and is numerically different as for example, Peter, an individual, a person, and a hypostasis. Persons do not differ from one another in substance, but rather in the accidents. The person is defined as a substance plus accidents. Accidents are what individuate a person. Person then is, as with Boethius, simply the particular instance of a general substance, humanity, particularized, that is, by accidental qualities. Substance is one reality and person another. Substance means the common species including the persons that belong to the same species- as for example, man- whereas person indicates an individual, the Father, the Son, the Holy Spirit, Peter, Paul. ${ }^{14}$ In the case of Christ one cannot speak of one nature made of Divinity and Humanity as one can in the case of the individual made up of soul and body. It is very important to realize that by the Incarnation there not another nature emerging. Only what happens is the unity of Divine and Human natures without confusion, without separation and without division. In this regard it is not possible to affirm a single nature in Christ himself because of the uniqueness of the union of Divinity and Humanity. It is only Christ. Simply the Divine Person of Jesus Christ. Who is truly Divine and truly Human. Boethius and John of Damascus sustained efforts to tie together the notions of "person" and "nature" and explained the relation in terms of Aristotelian categories of substance, accident, and individuation. Person was made into something subsisting from soul and flesh, but was not made a person or substance or nature. And insofar as he is subsistent, the person is composite; but insofar as he is the Word, the person is simple. Richard of St. Victor introduced the term "incommunicable." For him Divine Persons are "incommunicable existence" and person more generally is "the singular reality existing per se according to the rational mode of existence. Nestorians posited a plurality of persons in Christ. The central distinction between person and nature was that what was said of the Divine Persons as distinctively Persons could not be said of the Divine Nature. The Divine Will and the Human Will cannot be distinctively attributed to his Person but rather this should be simultaneously to the Person of Jesus Christ. The reason why nothing could be distinctively attributed to the Divine Persons was because there was nothing more to say about them than what could be described of their Divine Nature. All that was left, were their names, the Father, and the Son, and the Holy Spirit, and their inter-relations which did not belong to their Nature as Divine.

Borden Packer Bowne and John MacMurray addressed the question of the relation between the personal and the impersonal. The field of the personal is defined

${ }^{14}$ Cf. Patterson, Chalcedonian Personalism, 23. 
by a personal attitude to other persons. The field of the anthropological sciences by an impersonal attitude. MacMurray is critical of the Cartesian privileging of the cogito with its commitment to the primacy of the objective or speculative thought. In contrast, he gives a central place to the self as personal agent in relation to other persons; thought as such is for him, always ordered to the personal and to the actions that persons carry out in relation to others. He posits the primacy of personal agency over objective thought ${ }^{15}$. Regarding the relational character of persons, the unit of personal existence is not the individual, but persons in personal relation; and that we are persons not by individual right, but in virtue of our relation to one another. Kant's "thing-in-itself" as unknowable lead not simply to a blind spot for the personal but to its complete subordination to some form of the absolute spirit and thus to a loss of the particularity of the personal ${ }^{16}$.

Theological reflection has not generally understood the Genesis mention of "image and likeness" as referring to some physical or representational likeness. Imago dei refers to rationality. That which sets man apart from non-human species is his capacity for reason, and it is this which connects with the Divine Logos and opens up the possibility of Divine-Human relationship of a kind unavailable to sub-human creatures. An alternative approach proposed by Karl Barth characterizes the image and likeness of God in mankind as his capacity for relationship. As God is tri-personal, Divine Persons related and relating to each other so too humans-with male and female constituting the fundamental duplex form of the species-are marked by a capacity for interpersonal relation.

Chalcedonian anthropology has distinguished between "human nature" and "human person." We cannot speak of Divine Nature as qualified to belong to a unique Divine Person since it is the same Divine Nature of the three Divine Persons. To talk of for example the Divine Nature of Jesus Christ is exactly the same as saying God. This is because Divine Nature is the same Divine Nature. The three are Divine Persons not three Divine Natures. Care should be taken when one mentions Divine Nature of the person of Jesus Christ. This should not be interpreted to mean that there is such a Divine Nature of the Father, another Divine Nature of the Son, and another Divine Nature of the Holy Spirit. This would point to three Gods (three different Divine Natures). Rather, mention of the Divine Nature of Jesus Christ must be understood as a distinction from the Human Nature. Likewise, one ought not to be misled by the mention of the "Human Nature of Jesus Christ" as if it say there was an exceptional Human

\footnotetext{
${ }^{15}$ Cf. Bogumił Gacka, Personalizm europejski-European Personalism (Warszawa: Stowarzyszenie Ekosystem-Dziedzictwo Natury, 2014), 44-78.

${ }^{16}$ Cf. Patterson, Chalcedonian Personalism, 92.
} 
Nature of Jesus alone. Rather, one should understand this as a distinction of the Human Nature from the Divine Nature. For Jesus' Human Nature is not different from the universal Human Nature proper to other all human persons. Jesus Christ who is true man-cannot have a human nature of Christ applicable to him alone. Otherwise he would not be true human. With this understanding we are able to see that we have the same Human Nature as that of Jesus. What differentiates us, is the reality of personhood which is uniqueness and relatedness simultaneously. It is not open to us to describe the relation between natures and Person in Christ other than to say that it is hypostatic, and this applies whether we are considering the matter from an objective or an experiential point of view. Not only have we not been able to move beyond the label "hypostatic"; even in principle, we cannot do so. How are the divine and human natures united in Christ? All that can be said is that the union is hypostatic or personal. The principle that persons and natures must not be confused is consistent with this response. In line with this also is the conviction that the concept of consciousness cannot mediate between Person and Nature in Christ.

\section{Human Nature is like that of Christ}

It is interesting to see how Patterson changes the "order" in his Chalcedonian Personalism. Normally we say "The Word became man" as if it were Christ has human nature like ours, but for Patterson instead our human nature is like that of Christ. Patterson says, that Chalcedonian anthropology not only takes Christ as the exemplary human being, but also and more particularly uses the person-nature distinction to set the constraints for our concept of human nature as more generally understood. If Christ is our example, then we have a personhood like his. Indeed, ultimately we have a personhood which participates in his. But also a human nature like his. As a first approximation, we can say that our nature, as with Christ, is all that we can describe about ourselves. ${ }^{17}$ With this understanding one is able to see the meaning of reference to Christ as the "New Adam" for the redemption and the salvation in Christ does not restore human nature to the first Adam. But "recreates" it to a higher level-a level of the sons and daughters of God. Human nature after the Incarnation and through Christ and with Christ and in Christ human persons can call God "Abba-Father." Patterson further acknowledges the fact that, "Persons, being non-describable, cannot in themselves be included in the description." ${ }^{18}$ Rufus Burrow, Jr. has

\footnotetext{
${ }^{17}$ Cf. Patterson, Chalcedonian Personalism, 169-170.

${ }^{18}$ Cf. Ibidem, 169.
} 
expressed the same in his work, Personalism: A Critical Introduction. ${ }^{19}$ In this regard Patterson permits that, "[...] we are free to follow wherever our researches and curious wanderings lead us, always, needless to say, with an eye to the truth." ${ }^{20}$ Patterson respects the reality of free will and freedom. Free will and freedom is a reality also among other realities of what it entails to be a person. But this free will and freedom is not to be haphazardly taken as many "sciences" today misinterpret free will and freedom as to do whatever one wills with the practical implication of doing whatever the "I" wants. This kind of understanding of "will" is a "will" isolated from intellect-a kind of will in a vacuum not served by the intellect-the intellect which pursues the truth. Patterson guards the true freewill and freedom by the fact that sight of the truth is not to be veered away from. Then the guiding principle becomes the truth. Nothing but the truth in all our researches and curious wandering, nothing but the truth.

\section{THE PERSON-NATURE RELATION}

Persons as such are unique and irreplaceable. Of course, nature is also unique and irreplaceable but this is broad in as far as one nature can be the same among different persons. But person is not common to other persons. Let us now follow this under the themes of: Trinitology, Christology and Anthropology.

\section{Trinitology}

First of all, care should be taken when the term "particular person" is used. Particular person, might imply an instance or a part of nature existing in this unique person. And so it would require a unification of all persons to come up with a complete nature. Yet we know that every unique person has the fullness of nature. At the same time it might imply that this concrete person has no full nature. The First Person of the Trinity has the fullness of Divine Nature not part, and so is the Second Person and the Third Person. It is in this regard that I prefer the term "uniqueness" rather than "particularity" in our understanding of persons. Persons are always persons-in-relation. Relational definition of "person" is at the Centre of Trinitarian theology whereby Divine Persons exist only in relation to one another. ${ }^{21}$ The term "love" refers to the relation between persons. Love is the visible sign of personhood. The observed actions are such as to reveal the relation between persons rather than

\footnotetext{
${ }^{19}$ Cf. Rufus Burrow Jr., Personalism: A critical Introduction (St. Louis: Chalice Press, 1999).

${ }^{20}$ Cf. Patterson, Chalcedonian Personalism, 169.

${ }^{21}$ Cf. Ibidem, 39-40.
} 
hinder or even destroy it; truly loving actions imply an ongoing relation between persons. Out of Love the Father begets the Son and out the same love the Father and the Son Spirate the Holy Spirit in a single Spiration. The truth of Begetting and Spiration does not in any way lead to the Generation of another nature. The Nature is One Divine Nature but Three Divine persons.

\section{Christology}

A fundamental distinction within Christology is that between "person" and "nature"; this distinction is not reducible to the distinction between Human and Divine. Person and nature cannot be subsumed under any superordinate substantial category. The relation in Christ's personhood to his human nature should avoid any implication of Christ with a less than fully human nature, or a less-fully hypostatic union. ${ }^{22}$ Person and nature do not belong to the same reality even though they each refer to a unity, a single Human and Divine Being. Person cannot be fitted into the conceptual apparatus constrained by substance-accident, individual-general and similar distinctions. Person and nature are distinct realities, so that talking about the Person of Christ as Divine does not in any way mean that there is something deficient about his human nature. Insofar as it is a human nature, it is fully complete. Everything we can say about a human person would be an affirmation about his or her nature as human. This includes the intellect, the will, the capacity for action as well as everything that we might treat as biological. And yet we would want to affirm that there is a more than what is encompassed by such affirmations. The language used in communicatio idiomatum is not a statement of identity (numerically and in every respect identical), nor does it express a part-whole or an element-set relation. Rather it expresses a relation between the Divine Person of the Son, and the two Nature, Divine and Human that is, sui generis, the hypostatic. ${ }^{23}$

\section{Anthropology}

Human persons are free, possessing a soul, a will, and are able to act rationally. Rationality is a truth that belongs to persons. Persons are realities, rather than entities or things-their existence comes from God, and they are not to be identified with anything in nature and can be described only negatively or apophatically, as is the case of the Divine Persons. The extension of the notion of person to anthropology suggests that human persons-like Divine Persons are unique. Relations between persons are essential for determining their identity. The replica "wife" is not treated as wife by the husband because the relationship between the two of them would

\footnotetext{
${ }^{22}$ Cf. Ibidem, 138.

${ }^{23} \mathrm{Cf}$. Ibidem, 126.
} 
be different from that which obtained with his actual wife. ${ }^{24}$ The foundation for uniqueness and unrepeatability is in the relation with the Divine, that is, the address of the Divine Subject, God, provides such a foundation. Human persons are only such in virtue of their relationship with Christ. This sees human personhood in its fullness as an eschatological reality; it defines the outworking of human personhood in this life in terms of the way Christ displayed it, most directly in his relation with the heavenly Father. Insofar as someone reflects Christ's Personhood in their life, then they show forth themselves as persons. However Persons are not describable in terms of natural category since they are unique and unrepeatable. As being in relation, they are not discrete entities.

While we cannot give any description of persons as such, we can acknowledge each and every person as an absolutely unrepeatable reality. We also recognize that persons are always associated with natures. ${ }^{25}$ This reality that persons are always associated with natures helps us to differentiate between Divine Person and human person. This connectedness between nature and person is a constant reminder that there are Divine Persons and human persons. Divine Persons being eternal in the sense that they have no beginning and have no end while human persons have a beginning namely created by God,-from God, but once created go on forwards to eternity. To each and every human being there belongs a reality that is other than natural. The doctrine of the immediate creation of the human soul, though expressed in substantialistic language points to the appreciation this truth. ${ }^{26}$

\section{IMPLICATIONS OF THE PERSON-NATURE RELATION}

The unbreakable link between nature and person leads us to: God who is; capable of Act; capable of love; worthy of worship. It also implies supernatural revelation, faith, reality, true unity in diversity and Insufficiency of Psychological sciences.

\section{God Who Is and Who Acts}

Person-Nature relation leads to God who IS and capable of Act. This is what Rufus Burrow means when he says "To Be Is to Act." ${ }^{\text {" } 7}$ A God who is Love. God

${ }^{24}$ Cf. Ibidem, 139.

${ }^{25}$ Cf. Ibidem, 137.

${ }^{26}$ Cf. Ibidem, 138-139.

${ }^{27}$ Cf. Burrow, Personalism, 92; Karol WojtyŁa, The Acting Person, translated by Andrzej Pотоскі (Dordrecht: D. Reidel Publishing Company, 1979). 
who is capable of self-giving. There is an inherent Divine consciousness. The procession of the Son from the Father, and the mission of the same, and human consciousness in Christ is entirely to be identified with that mission. The human consciousness in Christ is purely and simply an awareness of the Father's mission, in the Holy Spirit, to which he has freely consented. This is entirely the "content" as it were of the human consciousness that Christ experienced on earth. ${ }^{28}$ That mission, in turn, is nothing more nor less than the outworking of the Father's Generation of the Son from eternity, and is fulfilled in the power of the Holy Spirit, who proceeds from both the Father and the Son.

\section{Supernatural Revelation}

The reality of the Holy Trinity comes to us through Supernatural Revelation, that is, through Sacred Scriptures and the Incarnate Son of God. Whereas reason can help us to appreciate the reality of the Three Divine Persons, it cannot lead us to the reality of Divine Persons unaided by Supernatural Revelation. Without Special Revelation it is not possible to talk of One God-three Divine Persons. Reason alone can arrive at the existence of One God (in this case Divine Nature for there is only one Divine Nature). The reality of the Three Divine Persons is a Truth of Supernatural Revelation. Some philosophers like Aristotle were able to arrive at the Nature of God (the unmoved mover). Such a God cannot be adored, worshipped or prayed to. Because he is unmoved. He is incapable of act, incapable of love, incapable of self-giving. In line with Rufus Burrow, we can say that, such a "God" is NOT, simply because he cannot act, yet "to be" is "to act." Such a God cannot be "God with us"-Incarnate, because Incarnation is only possible because God is The Trinity. But, because the God of supernatural revelation is Tri-Personal, He can be worshiped, adored and prayed to. Relying one natural reason alone, philosophers were able to recognize the existence of Divine Nature. But this Nature is passive. That is why, philosophers like Xenophanes, Aetius, Philodemus, among other were able to mention that the gods are in the heavens and are not concerned with human persons' affairs. ${ }^{29}$

Chalcedonian anthropology makes recourse to Supernatural Revelation. Dr. Patterson's appreciates supernatural revelation as indispensable for our understanding of the human person. He writes, "Though we humans have made much progress in exploring the nooks and crannies of our nature, there is still

\footnotetext{
${ }^{28}$ Cf. Ibidem.

${ }^{29}$ Cf. Brad Inwood, Lloyd P. Gerson, Hellenistic Philosophy (Cambridge: Hackett Publishing Company, 1997); Adam Drozdek, Greek Philosophers as Theologians: The Divine Arche (Burlington: Ashgate Publishing Limited, 2007), 222.
} 
much that is a mystery, much that we do not have the capacity by ourselves to uncover. It is in the Incarnate Word, that is, by pondering the Incarnation that much of that mystery is or at least can be made clearer to us insofar as we have the capacity to receive it. Christ... fully reveals man to himself." ${ }^{30}$ It is not possible to come to a sustainable conception of the human person without looking at the Incarnate Son of God.

\section{Faith}

We can now compare philosophy and faith as, "I know" versus "I believe" When one says "I know" then he does not need to believe what he fully knows because he knows. But when one says, "I believe" he implies "Faith" of course not irrational faith, for real faith presupposes some level of knowledge. "How will they believe if they have not been told" (Romans 10:14). Revelation actually tells us, such that we can have some prerequisite knowledge required for faith. For example, a dog cannot believe because it has no reason. But man can believe because he has a reason to believe. What revelation does is that it gives us "reason(s)" to believe in a revealed Truth-in this case the Holy Trinity.

\section{Reality}

As tacitly implied by Bowne, and explicated by Brightman, Bertocci, Knudson, and Burrow, Person is presented as the key to reality. "[...] person is reality. More than any other principle or category, more than any model provided by science, or mathematics, person is the best key to unravelling or explaining as far as possible the mysteries of reality and the universe. ${ }^{" 31}$ Cataphatically defined, person is not nature. But of course there is not such a reality of person devoid of nature. For such would only tantamount to idea of person not to reality of person. It would only be an idea empty of substance or empty of reality and would translate into idealism. Likewise Divine Nature without person would only lead to a passive Divine Nature that cannot be moved. One that cannot be related to. Therefore, from there relation of Nature and Person in God we are able to see that prayer, worship and adoration to God is only possible when God is a personal God. The reality of personhood is very important in our relation to God. Because prayer, worship, adoration to God is only possible when God is perceived as a personal God. The Christian conception of God cannot be Divine Nature alone and it cannot be person alone, but rather Divine nature and person simultaneously. Without

\footnotetext{
${ }^{30}$ Patterson, Chalcedonian Personalism, 135.

${ }^{31}$ Burrow, Personalism, 110.
} 
one being opposed to the other, without separation, without confusion, without mixture but God as Such.

\section{True Unity in Diversity}

Christian Ecumenism can only be possible if God is conceived as Divine and Three Persons simultaneously. For this is a reality so central that it cannot be excluded in any step towards Ecumenism. Because that is a starting point for real relations, not just diplomatic relations but real ontological relations. Real Ecumenism should be personalistic. Unity in diversity is only possible with this conception of God as personalistic. The role of the Holy Spirit remains paramount in making this unity in diversity possible. Marriage itself is only possible because of this reality of unity in diversity. That, there is unity in nature of man and woman but at the same time there is diversity as male person and female person. This enables a mutual giving of one person to another in marital love. Nature without real diversity is sterile and passive. Love and action are not possible if there is no personification in nature.

\section{Insufficiency of Psychological sciences}

In as far as psychology may not be able to touch the complete reality of human person there is need for supernatural revelation especially as given in the Person of Jesus Christ. This makes possible the touch with essence of personhood. The sacrament of Penance as is in the Catholic Church compared with psychological sciences, the Sacrament of Penance touches both the "immanent" person and the "economic" person simultaneously, something different from the psychological sciences which concern themselves more with the "economic" person. The sacrament of Penance is giving both human life in earthly existence and eternal life-a fundamental truth of what it means to be a person. The human person has a beginning. He is created but does not end in annihilation. Once created he has to be forever. This reality is not sufficiently handled by the psychological sciences alone. Yes, the concrete earthly existence is a reality of every human person and is very important, right from the moment of conception until the end of that person's earthly life. But that is not all. The temporal moment in the life of a human person prepares for the future eternity.

\section{GENERAL CONCLUSION}

In conclusion we can say that, the Mystery of the Holy Trinity, The Person of Jesus Christ, The Person-Nature relation and the implications of this relation- 
ship among these realities gives us the more comprehensive way of perceiving the human person. And, because of the mystery of the Incarnation, the Second Divine Person of the Holy Trinity cannot be separated the Divine Nature and the Human Nature. He is the Hypostatic union but one Divine person. Before and after the Hypostatic Union there is in Christ One Person. The Divine Person Jesus Christ is True God and True Man at once. Chalcedonian Personalism captures the truth of Divine Persons and that of human persons at once. Psychological sciences can help, and social structures like the state can help to protect the human person's freedom, rights and liberty. But when the truth of Divine Persons, and Divine Grace is closed out, the human person cannot realize himself or herself. Psychology and other sciences cannot be a replacement for the sacrament of penance because the sacrament deals with the ontological totality of the human person in relation to the Divine Persons and the horizontal relation to the human persons simultaneously. Psychology operates more at the horizontal level. The relation between Person and Nature is a constant reminder that there is not only one nature-the human nature, but there is first of all Divine Nature. Person is a subject to whom the only proper and adequate attitude is love. Supernatural Revelation and the Action of God through Grace (the Holy Spirit) is indispensable for the human person to realize his or her true self as a person.

\section{BIBLIOGRAPHY}

Burrow, Rufus Jr. Personalism: A critical Introduction. St. Louis: Chalice Press, 1999. Denzinger, Henry. The Sources of Catholic Dogma. Freiburg: Herder \& Co., 1954.

Drozder, Adam. Greek Philosophers as Theologians: The Divine Arche. Burlington: Ashgate Publishing Limited, 2007.

Gacka, Bogumił. Personalizm europejski-European Personalism. Warszawa: Stowarzyszenie Ekosystem-Dziedzictwo Natury, 2014.

Inwood, Brad, Gerson, Lloyd P. Hellenistic Philosophy. Cambridge: Hackett Publishing Company, 1997.

John Paul II. Crossing the Threshold of Hope. Translated by McPhee, Jenny, McPheE, Martha. London: Jonathan Cape, 1994.

Muelder, Walter G. "Personalism.” In The Westminster Dictionary of Christian Ethics, editors James F. Childress, John Macquarrie, 469-470. Philadelphia: Westminster Press, 1986.

Patterson, Colin. Chalcedonian Personalism: Rethinking the Human. Oxford: Peter Lang Ltd, 2016. 
Ratzinger, Joseph. "Concerning the Notion of Person in Theology." Communio 17(1990): 439-454.

Ratzinger, Joseph. Faith, Philosophy and Theology. Minnesota: College of St. Thomas Press, 1985.

Vatican Council II. "Gaudium et spes." In Vatican Council II: Constitutions, Decrees, declarations, ed. Austin Flannery. New York: Costello 1996.

WojtyŁa, Karol. “The Personalistic Norm.” Personalism: Science Philosophy Theology, 11(2006): 45-48.

WojtyŁa, Karol. The Acting Person. Translated by Andrzej Ротоскі. Dordrecht: D. Reidel Publishing Company, 1979.

\section{PERSONALIZM CHALCEDOŃSKI WEDŁUG COLINA PATTERSONA}

S T R E S Z C Z E N I E

Colin Patterson (Melbourne, Australia) prezentuje personalizm Soboru Chalcedońskiego (451). Przedstawia misterium Trójcy Świętej, osobę Jezusa Chrystusa i obraz Boży w człowieku. Szczególną uwagę poświęca relacji osoba-natura w trynitologii, chrystologii i antropologii.

Słowa kluczowe: sobór chalcedoński; personalizm; relacja; osoba; natura. 